\title{
Karakteristik dan Problematik Perlindungan Motif Lubeng Tenun Troso
}

\section{Misbahul Awang Sakti}

Fakultas Hukum Universitas Diponegoro

Awang199663@gmail.com

\section{Kholis Roisah}

Fakultas Hukum Universitas Diponegoro

r_kholis@yahoo.com

DOI: $10.23917 /$ jjr.v9i2.8908

\begin{abstract}
Submission
Track:

Received:

25 September 2019

Final Revision:

13 Desember 2019

Available online:

17 Januari 2020

Corresponding

Author:

Misbahul Awang

Sakti

Awang199663@gmail.com

\section{ABSTRACT / ABSTRAK}

Tujuan : Tulisan ini bertujuan untuk mengetahui karakteristik dan problematik dalam melakukan perlindungan hukum terhadap hak cipta motif lubeng tenun ikat troso. Penelitian ini merupakan penelitian hukum empiris menggunakan data primer dan data sekunder. Pendekatan penelitian yang digunakan adalah pendekatan kualitatif. Teknik pengumpulan data dilakukan dengan cara wawancara dan studi pustaka. Hasil penelitian menunjukkan bahwa motif lubeng memiliki karakteristik yang unik dibandingkan dengan motif tenun lainnya. Perlindungan terhadap tenun troso secara keseluruhan belum diatur oleh pemerintah dan motif lubeng tenun ikat troso belum didaftarkan di Ditjen KI. Hambatan dalam memberikan perlindungan hukum yaitu masih banyak pengrajin dan pengusaha tenun troso yang belum memahami adanya Undang-Undang Hak Cipta. Hal ini dikarenakan adanya tingkat kesadaran hukum masyarakat terhadap Undang-Undang Hak Cipta yang rendah, prosedur pendaftaran hak cipta yang berbelit-belit, dan budaya para pengrajin dan pengusaha tenun troso yang beranggapan bahwa suatu penjiplakan atau peniruan motif tenun troso merupakan suatu hal yang sudah biasa. Upaya dari pemerintah untuk mengatasi hambatan tersebut adalah dengan mengadakan sosialisasi kepada para pengrajin dan pengusaha tenun ikat troso. Pemerintah diharapkan lebih kreatif dalam melakukan kegiatan sosialisasi dan menambah jumlah agenda sosialisai akan pentingnya pendaftaran hak cipta kepada para pengrajin pengusaha tenun troso sehingga perajin memiliki kesadaran akan pentingnya pendaftaran hak cipta.
\end{abstract}

Keywords:perlindungan, motif lubeng, tenun troso 


\section{PENDAHULUAN}

Indonesia sebagai Negara kesatuan yang terdiri atas beragam suku bangsa dan adat istidat yang berbeda-beda, tentunya mimiliki keragaman kekayaan budaya yang menjadi ciri khas dan kebanggaan bangsa Indonesia. Salah satu kekayaan budaya yang menjadi kebanggaan bangsa Indonesia adalah keragaman kain tradisional, khususnya kain tenun ikat. Tenun ikat adalah kriya tenun Indonesia, berupa kain yang ditenun dari helaian benang lungsin yang dalam proses pembuatannya sebelumnya diikat dan di celupkan ke dalam zat pewarna pakaian/pewarna alami. Dan alat yang digunakan untuk menenun adalah alat tenun bukan mesin (ATBM) dan alat tenun mesin. Sebelum ditenun, helai-helai benang dibungkus (diikat) dengan tali plastik/rafia sesuai dengan corak atau pola motif yang diinginkan. Ketika dicelupkan ke dalam zat pewarna, bagian benang yang diikat dengan tali plastik tidak akan terwarnai.

Tenun ikat adalah tenun yang dalam proses pembentukan motifnya didapat dengan mengikat benang dan menggunakan tali yang tidak tembus warna, diikat dengan tali rafia atau tali plastik. Bagian yang tidak diikat akan menyerap warna celupan, kemudian benang-benang yang telah diwarnai di tenun dengan alat tenun bukan mesin (ATBM), sampai membentuk motif yang diinginkan. (Sumartono, 2012: 12).

Kain tenun ikat sudah menjadi produk nasional yang sangat dibanggakan oleh bangsa Indonesia dan sudah terkenal di mancanegara. Indonesia memiliki beragam jenis kain tenun ikat dengan motif yang beragam dan berasal dari masing-masing daerah, antara lain Kalimantan dengan tenun sambas, Sumatera dengan tenun songket jambi, Sulawesi dengan tenun donggala, Bali terkenal dengan tenun gringsing dan tenun endek, Lombok dengan tenun yang khas yakni tenun sasak, dan tidak tertinggal yakni daerah Jawa, khususnya daerah Jawa Tengah yang terkenal dengan salah satu tenun yang khas dari daerah Jepara yakni Tenun Ikat Troso yang berada di daerah troso Kabupaten Jepara. Kain tenun ikat Troso sendiri sudah sangat terkenal di nusantara, dan mancanegara dengan beragam keindahan jenis motif yang menawan. Tenun troso mempunyai ciri khas tersendiri dalam bentuk motif dan tenunan, banyak motif yang terkenal dari tenun troso, antara lain motif ceplok bunga, motif tumbuhtumbuhan, motif SBY, motif Gapuro Mantingan, motif tenun baron, tenun Blangket Pelangi, tenun Blangket Jumput dan tidak kalah terkenal yakni motif lubeng. 
Motif adalah desain yang dibuat dari bagian-bagian bentuk, berbagai macam garis atau elemen-elemen, yang terkadang begitu kuat dipengaruhi oleh bentuk-bentuk stilasi alam, benda, dengan gaya dan ciri khas tersendiri. (Suhersono, 2005:13)

Motif Lubeng tenun ikat Troso merupakan kekayaan intelektual yang dihasilkan oleh masyarakat asli desa Troso Kabupaten Jepara. Sehingga motif lubeng tenun ikat troso bisa dikatakan suatu hak cipta yang harus dilindungi oleh pemerintah. Pasal 1 undang-undang Hak Cipta Nomor 28 Tahun 2014 tentang Hak Cipta. Hak Cipta adalah hak eksklusif pencipta yang timbul secara otomatis berdasarkan prinsip deklaratif setelah suatu ciptaan diwujudkan dalam bentuk nyata tanpa mengurangi pembatasan sesuai dengan ketentuan peraturan perundang-undangan.

Perlindungan hukum terhadap motif lubeng sangat diperlukan, guna untuk menjamin perlidungan hukum bagi perajin/pengusaha yang sudah menciptakan sebuah karya cipta, dan supaya motif lubeng tidak diklaim oleh daerah lain, maupun negara lain. Motif lubeng merupakan suatu ciptaan yang harus dilindungi seperti yang tercantum pada pasal 40 huruf $\mathbf{J}$ Undang-undang Nomor 28 tahun 2014. Penjelasan pasal 40 huruf J Undang-undang Nomor 28 tahun 2014 adalah yang dimaksud dengan " karya seni batik" adalah motif batik kontemporer yang bersifat inovatif, masa kini, dan bukan tradisional. Karya tersebut dilindungi karena mempunyai nilai seni, baik dalam kaitannya dengan gambar, corak, maupun komposisi warna. Yang dimaksud dengan "karya seni motif lain" adalah motif yang merupakan kekayaan bangsa Indonesia yang terdapat di berbagai daerah, seperti seni songket, motif tenun ikat, motif tapis, motif ulos, dan seni motif lain yang bersifat kontemporer, inovatif, dan terus dikembangkan. Untuk itu sangat dibutuhkan peranan pemerintah dalam melaksanakan perannya sebagai penegak hukum dan sadar akan pentingnya perlindungan hukum bagi karya cipta terutama seni motif lubeng tenun Troso. Perlindungan hukum terhadap motif lubeng, juga akan berguna untuk merangsang aktifitas kreatif, inovatif para perajin/pengusaha untuk terus-menerus berkarya dalam menciptakan desain motif-motif tenun yang baru.

Perlindungan hukum adalah suatu kewajiban yang harus dilaksanakan pemerintah terhadap warga negaranya. Menurut Philipus M. Hadjon, prinsip perlindungan hukum bagi rakyat tidak terpisahkan dari tujuan awal diadakannya negara Indonesia sebagaimana dirumuskan dalam Alinea IV Pembukaan UUD 1945 yang antara lain menyatakan: "kemudian dari pada itu untuk melindungi segenap bangsa Indonesia dan seluruh tumpah darah 
Indonesia...maka disusunlah kemerdekaan Indonesia dalam suatu Undang-undang dasar...”. (Thalib, 2006:54)

Analisis alinea IV ini dalam hubungannya dengan perlindungan hukum adalah Indonesia merupakan Negara hukum. Sesuai tujuan Negara dalam alinea keempat UUD 1945, Ini berarti bahwa Indonesia adalah Negara yang berdasarkan atas hukum. Dengan sendirinya perlindungan hukum menjadi unsur esensial serta menjadi konsekuensi dalam Negara hukum. Negara wajib menjamin hak-hak hukum warga negaranya. Karena perlindungan hukum merupakan pengakuan harkat dan martabat warga negaranya sebagai manusia.

Perlindungan hukum merupakan suatu hal yang melindungi subyek subyek hukum melalui peraturan perundang-undangan yang berlaku dan dipaksakan pelaksanaanya dengan suatu sanksi. Salah satu sifat dan sekaligus merupakan tujuan dari hukum adalah memberikan perlindungan (pengayoman) kepada masyarakat. Maka dari itu rumusan diatas mendasari prinsip pengakuan dan perlindungan hak asasi manusia dan prinsip negara hukum yang diarahkan pada usaha-usaha untuk mencegah terjadinya sengketa/konflik antara pemerintah dengan rakyat maupun rakyat dengan rakyat itu sendiri.

Perlindungan hukum yang dibutuhkan pengusaha/perajin tenun troso salah satunya adalah pendaftaran hak cipta. Mengingat karena kurangnya pengetahuan tentang hak cipta bagi pengusaha/perajin tenun troso dan juga kesadaran tentang arti pentingnya perlindungan hak cipta bagi pengembangan kebudayaan, peningkatan kreativitas masyarakat dan pembangunan ekonomi. Maka dari itu diharapkan pemerintah dapat melaksanakan upaya perlindungan hukum terhadap motif-motif tenun Troso.

Pendaftaran ciptaan diatur dalam undang-undang nomor 28 tahun 2014 tentang hak cipta dimaksudkan untuk mengatur pendaftaran ciptaan agar dapat menciptakan ketertiban dan keteraturan masyarakat di bidang hak cipta. Tujuan pendaftaran hak cipta itu sendiri adalah untuk menetapkan hak pencipta dan menjamin perlindungan hukum terhadap karya cipta yang dihasilkan. Salah satunya yakni motif Lubeng tenun ikat Troso.

Pendaftaran hak cipta dapat dilaksanakan melalui secara offline maupun online. Pendaftaran secara online yaitu pendaftaran yang cara mendaftarkan hak cipta tidak langsung datang ke tempat, tapi bisa melalui internet. Dengan cara mengakses alamat tersebut di https://e-hakcipta.dgip.co.id/. Link tersebut terhubung langsung dengan Ditjen KI pusat.

Pendaftaran hak cipta motif lubeng tenun ikat troso sangat diharapkan oleh pengusaha dan perajin, karena pendaftaran hak cipta memegang peranan penting dan manfaat bagi 
pengusaha dan perajin, manfaat tersebut antara lain : dapat memberikan perlindungan hukum terhadap hak cipta motif lubeng tenun ikat troso, untuk menghindari bentuk pelanggaran yang tidak diinginkan, contohnya yaitu klaim dan plagiarisme, memperoleh manfaat ekonomi dari karya cipta motif lubeng tenun ikat troso, memberikan daya semangat untuk mengembangkan daya kreatif, inovatif bagi pengusaha dan perajin untuk menciptakan motif- motif tenun yang baru. Apabila hak cipta motif lubeng tenun ikat troso tidak didaftarkan akan menimbulkan berbagai macam permasalahan, yakni timbulnya rasa khawatir yang dirasakan pengusaha dan perajin misal karya ciptanya diklaim oleh orang lain atau negara lain, ketika motif lubeng tenun ikat troso diklaim atau dibajak, tentunya para pengusaha dan perajin akan merasakan kecewa dan kurangnya rasa semangat untuk menciptakan motif lain yang lebih kreatif dan inovatif. Sehingga hal tersebut akan berdampak bagi ekonomi para pengusaha dan perajin tenun ikat troso.

\section{METODE PENELITIAN}

Penelitian ini merupakan penelitian yang menggunakan metode yuridis empiris dengan pendekatan yang digunakan adalah pendekatan kualitatif terkait perlindungan Hak Cipta motif lubeng tenun ikat troso menurut Undang-undang No. 28 Tahun 2014 tentang hak cipta. Lokasi penelitian ini dilakukkan di home industry Lokasi penelitian ini dilakukan di Home industry tenun ikat troso, Balaidesa Troso, Paguyuban tenun troso yang berada di desa Troso, Kecamatan Pecangaan, Kabupaten Jepara, dan pada Kantor Wilayah Kementrian Hukum dan HAM Jawa Tengah pada Bidang Administrasi Hukum Umum (AHU) dibawah Devisi Pelayanan Hukum dan HAM.

Penelitian ini menggunakan sumber data primer dan sekunder. Sumber data primer adalah data yang diperoleh langsung dari kehidupan masyarakat dengan cara wawancara dan observasi. Sumber data sekunder adalah semua publikasi tentang hukum yang merupakan dokumen. Publikasi tersebut terdiri atas (a) peraturan perundang-undangan. (b) buku-buku teks yang membicarakan sesuatu dan/ beberapa permasalahan hukum, termasuk skripsi, tesis, dan disertasi hukum. (c) jurnal-jurnal hukum. (d) putusan hakim. Publikasi tersebut merupakan petunjuk atau penjelasan mengenai bahan hukum primer dan bahan hukum sekunder. 


\section{HASIL DAN PEMBAHASAN}

Motif adalah desain yang dibuat dari bagian-bagian bentuk, berbagai macam garis atau elemen-elemen, yang terkadang begitu kuat dipengaruhi oleh bentuk-bentuk stilasi alam, benda, dengan gaya dan ciri khas tersendiri. (Suhersono, 2005:13). Motif merupakan benuk dasar dalam penciptaan sebuah desain pada suatu karya seni. Dalam hal ini meliputi segala bentuk ciptaan Tuhan (binatang, tumbuh-tumbuhan, manusia, gunung,air dll) dan hasil karya manusia berupa (bentuk garis geometris, dll).

Pada tenun tradisional, motif berfungsi sebagai penghias, setelah mengalami berbagai penyusunan dengan membentuk pola tertentu. Dilihat dalam suatu susunan pola pada tenun, akan didapatkan bentuk-bentuk motif hias yang berbeda sifatnya. Bentuk motif tersebut dapat diklasifikasikan ke dalam beberapa golongan sesuai dengan bentuk dasar motif dan tata susunannya. Motif hias tradisional digolongkan menjadi 2 golongan besar yaitu (1) motif hias golongan geometris, dan (2) motif hias non geometris.

Kain tenun troso mempunyai banyak varian motif tenun yang bagus dan menawan, motif-motif tersebut yakni: Motif Lubeng, motif tenun baron, motif tenun Obama, motif rangrang, motif saraswati, motif blangket, motif CSM

\section{Motif Lubeng}

Motif lubeng, motif ini mempunyai ciri khas yakni bentuk geometris segi empat di tengah dan dalam proses pembuatannya motif lubeng ini menggunakan jenis benang lamen.

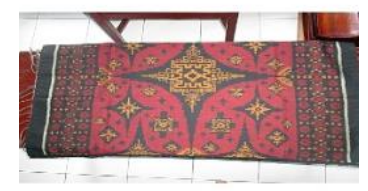

\section{Gambar 1: Motif Lubeng}

\section{Motif tenun baron}

Motif ini dibuat dengan menggunakan alat tradisional khusus yang bernama JANGKAR. Motif timbul dari kain tenun troso baron ini menimbulkan ciri khas motif tenun dibandingkan motif kain lainnya. 


\section{Gambar 2: Motif Tenun Baron}

\section{Motif tenun rang-rang}

Motif ini mempunyai ciri khas yakni terdiri dari motif garis-garis bertemakan simple namun bila dipakai terkesan elegan.

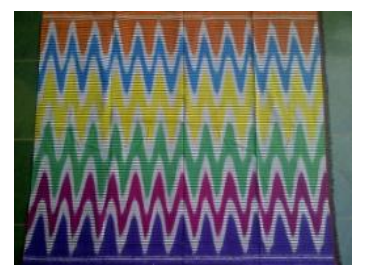

\section{Gambar 3: Motif Tenun Rang-rang}

\section{Motif tenun saraswati}

Motif ini sangat special karena motif ini terdapat banyak motif bunga bunga dengan kombinasi yang bagus.

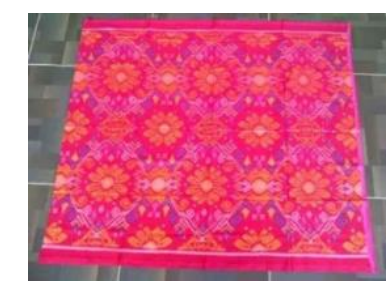

\section{Gambar 4: Motif Tenun Saraswati}

\section{Motif tenun blangket}

Motif ini mempunyai ciri kombinasi perpaduan warna yang sangat menarik.

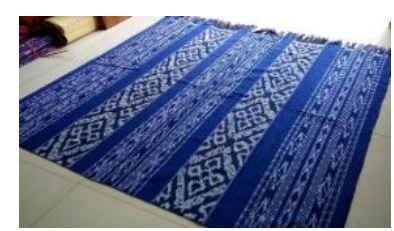

Gambar 5: Motif Tenun Blangket 


\section{Motif Tenun CSM}

Motif ini mempunyai ciri perpaduan antara motif bunga dengan symbol-simbol dan garis garis. Motif ini sering digunakan oleh para PNS untuk seragam dinasnya.

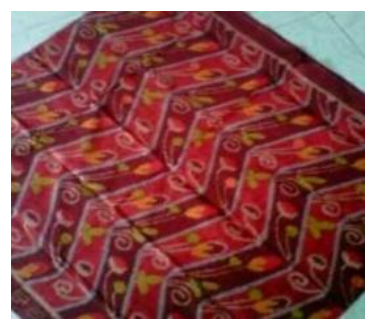

\section{Gambar 6: Motif Tenun CSM}

\section{Perlindungan hukum terhadap hak cipta seni motif lubeng tenun ikat troso ditinjau dari undang-undang nomor 28 tahun 2014 tentang hak cipta}

Perlindungan hukum terhadap kekayaan intelektual sangat penting dalam suatu negara, sebagai penghargaan atas hasil karya pencipta yang dihasilkan oleh kemampuan kekayaan intelektual manusia dan sebagai jaminan perlindungan hukum atas kekayaan intelektual yang sudah dihasilkan.

Menganalisa substansi pasal 40 ayat (2) Undang-undang Nomor 28 tahun 2014 yang berbunyi:"Perlindungan sebagaimana dimaksud pada ayat (1) dan ayat (2), termasuk perlindungan terhadap ciptaan yang tidak atau belum dilakukan pengumuman tetapi sudah diwujudkan dalam bentuk nyata memungkinkan penggandaan Ciptaan tersebut”.

Atas dasar tersebut di atas bahwa dalam ciptaan yang tidak atau belum dilakukan pengumuman tetapi sudah diwujudkan dalam bentuk nyata memungkinkan penggandaan ciptaan, secara tegas pemerintah memberikan perlindungan hukum yaitu dengan adanya instrument hukum yang berkaitan dengan hak cipta, maka dengan begitu tidak mengurangi isi pasal (1) point undang-undang Nomor 28 tahun 2014, yaitu:

"Hak Cipta adalah hak eksklusif pencipta yang timbul secara otomatis berdasarkan prinsip deklaratif setelah suatu ciptaan diwujudkan dalam bentuk nyata tanpa mengurangi pembatasan sesuai dengan ketentuan peraturan perundang-undangan"

Hak eksklusif dari hak cipta terdiri atas hak moral dan hak ekonomi. Hak ekonomi adalah hak untuk mendapatkan manfaat ekonomi atas ciptaan serta produk hak terkait. Menurut pasal 8 UU hak cipta hak ekonomi adalah Hak ekonomi merupakan hak eksklusif Pencipta atau Pemegang Hak Cipta untuk mendapatkan manfaat ekonomi atas Ciptaan. 
Ketentuan tersebut tersebut di atas memberikan keleluasaan kepada pencipta untuk mengalihkan ciptaannya kepada orang lain karena sifat hak ekonomi yang trasnsferable atau dapat dipindahtangankan/dialihkan, berdasarkan ketentuan pasal 9 UUHC bahwa:

1. Pencipta atau Pemegang Hak Cipta sebagaimana dimaksud dalam Pasal 8 memiliki hak ekonomi untuk melakukan: a. penerbitan Ciptaan; b. Penggandaan Ciptaan dalam segala bentuknya; c. penerjemahan Ciptaan; d. pengadaptasian, pengaransemenan, atau pentransformasian Ciptaan; e. Pendistribusian Ciptaan atau salinannya; f. pertunjukan Ciptaan; g. Pengumuman Ciptaan; h. Komunikasi Ciptaan; dan i. penyewaan Ciptaan.

2. Setiap Orang yang melaksanakan hak ekonomi sebagaimana dimaksud pada ayat (1) wajib mendapatkan izin Pencipta atau Pemegang Hak Cipta.

3. Hak ekonomi untuk menyewakan Ciptaan atau salinannya sebagaimana dimaksud dalam Pasal 9 ayat (1) huruf i tidak berlaku terhadap Program Komputer dalam hal Program Komputer tersebut bukan merupakan objek esensial dari penyewaan. (Zulva, $2016: 6)$

Hak moral adalah hak yang melekat pada diri pencipta atau pelaku yang tidak dapat dihilangkan atau dihapus tanpa alasan apa pun, walaupun hak cipta atau hak cipta telah dialihkan. Moral rights allow an author to assert authorship of his works and ensure he is always credited. An author can also prevent damage to his reputation by modification or distortion of his works. (Lona, 2012: 10)

Sehingga secara filosofis dengan lahirnya hak eksklusif sesuai dengan pasal di atas, bisa memberikan kepastian hukum kepada pencipta, untuk mendapatkan perlindungan hukum secara otomatis terhadap hak ciptanya, bahwa dengan adanya hak eksklusif yang diberikan oleh Negara bagi pencipta suatu karya dalam tindakan untuk mengumumkan, diperbanyak atau juga memberikan izin kepada orang lain untuk memperbanyak tanpa mengurangi hak yang melekat pada penciptanya, istrumen inilah yang membatasi dan juga melekat perlindungan hukum terhadap pencipta.

Undang-undang No. 28 Tahun 2014 tentang hak cipta memberikan arti bahwa ciptaan yang dilindungi dalam hak cipta yaitu, ciptaan dalam bidang ilmu pengetahuan, seni dan sastra yang diekspresikan dalam bentuk nyata, yang mempunyai ciri tersendiri untuk membedakan satu sama lain, baik berupa ide, prosedur dan konsep dalam mewujudkan yang tetap. Bahwa, dengan kata lain dalam mendapatkan perlindungan terhadap hak cipta tidak ada 
keharusan dalam untuk mendaftarkan untuk di diakui haknya, namun pendaftaran tersebut hanya sebagai keperluan bukti awal di pengadilan apabila timbul sengketa di kemudian hari terhadap ciptaan tersebut.

The goal of the copyright laws, in particular, is to provide a financial incentive to authors to produce original works by granting them control over the use of their products. In the absence of such control, plagiarism and unauthorized copying would diminish the rewards to innovative activity to the point where many potentially valuable works might not be produced. (Bensen, 1978: 67)

Bensen dalam jurnalnya diatas menjelaskan bahwa Tujuan undang-undang hak cipta, khususnya, adalah memberikan insentif finansial kepada pencipta untuk menghasilkan karya orisinil dengan memberi mereka kendali atas penggunaan produk mereka. Dengan tidak adanya kontrol semacam itu, plagiarisme dan penyalinan yang tidak sah akan mengurangi penghargaan terhadap aktivitas inovatif sampai pada titik di mana banyak karya yang berpotensi menghasilkan mungkin tidak diproduksi.

Dengan adanya pernyataan diatas mengenai perlindungan hukum secara mendasar untuk memberikan hak eksklusif terdapat beberapa unsur, dalam analisis penulis ukuran dalam lahirnya perlindungan secara otomatis memberikan sisi negatif terhadap si pencipta dan orang yang sering melakukan pelanggaran hak cipta ini, standarisasi dalam hak eksklusif ini seharusnya lebih dipertegas, dengan cara mewajibkan pencipta dalam mendaftarkan ciptaannya, dalam arti kewajiban mendaftarkan ini tidak sekedar menjaga terhadap karya ciptanya, namun kepastian hukum yang diharapkan. Selama ini pencipta maupun pemerintah tidak ada sinergitas bagaimana mengaplikasikan terkait implementasi perlindungan hukum.

Pendaftaran hak cipta di Indonesia bukan merupakan suatu keharusan bagi pencipta atau pemegang hak cipta, dan timbulnya perlindungan suatu ciptaan dimulai sejak ciptaan itu ada atau terwujud dan bukan karena pendaftaran. (Akmi, 2016: 8). Namun demikian, surat pendaftaran ciptaan dapat dijadikan sebagai alat bukti awal di pengadilan apabila timbul sengketa di kemudian hari terhadap ciptaan.

Dengan kata lain, pendaftaran suatu ciptaan bukanlah untuk mendapatkan hak cipta. Pendaftaran tidak lain dimaksudkan semata-mata hanya untuk memudahkan pembuktiannya saja. Pendaftaran hak cipta terkait perlindungan hukum terhadap hak cipta motif lubeng tenun ikat troso sangat dibutuhkan bagi pengrajin dan pengusaha tenun ikat troso. Karena pendaftaran hak cipta ini berguna untuk melindungi hak cipta motif lubeng tenun ikat troso 
agar tidak diklaim oleh daerah lain. Terkait pendaftaran hak cipta motif lubeng tenun ikat troso, ternyata motif lubeng tersebut belum didaftarkan di DITJEN KI. Hal ini disampaikan oleh zuhrul anam bahwa motif lubeng tenun ikat troso tersebut belum didaftarkan. Menurut penulis hal ini sangat disayangkan kenapa motif lubeng tenun ikat troso belum didaftarkan. Padahal ketika motif lubeng tenun ikat troso tersebut didaftarkan pastinya otomatis akan mendapatkan perlindungan hukum.

Terkait karya cipta motif lubeng tenun ikat troso secara khusus di atur dalam pasal 40 huruf J Undang-undang Hak cipta tahun 2014. Dalam undang-undang hak cipta tahun 2014 ini. ciptaan yang dilindungi adalah ciptaan dalam bidang ilmu pengetahuan, seni, dan sastra yang mencakup : (a) Buku, pamphlet, perwajahan karya tulis yang diterbitkan, semua hasil karya tulis lain; (b) Ceramah, kuliah, pidato, dan ciptaan lain yang sejenis dengan itu; (c) Alat peraga yang dibuat untuk kepentingan pendidikan dan ilmu pengetahuan; (d) Lagu dan alat music dengan atau tanpa teks; (e) Drama, drama musical, tari, koreografi, pewayangan, dan pantomime; (f) Karya seni rupa dalam segala bentuk seperti lukisan, gambar, ukiran, kaligrafi, seni pahat, patung, kolase; (g) Karya seni terapan; (h) Karya arsitektur; (i) Peta; (j) Karya seni batik atau seni motif lain; (k) Karya fotografi; (l) Potret; (m) Karya sinematografi; (n) Terjemahan, tafsir, saduran, bunga, rampai basis data, adaptasi, aransemen, atau modifikasi dan karya lain dari hasil transformasi; (o) Terjemahan, adaptasi, aransemen,transformasi, atau modifikasi ekspresi budaya tradisional; (p) Kompilasi ciptaan atau data, baik dalam format yang dapat dibaca dengan program computer maupun media lainnya; (q) Kompilasi ekspresi budaya tradisional selama kompilasi tersebut merupakan karya yang asli; (r) Permainan video, dan; (s) Program computer.

Penjelasan pasal 40 huruh J Undang-undang Nomor 28 tahun 2014 diatas adalah yang dimaksud dengan "karya seni batik" adalah motif batik kontemporer yang bersifat inovatif, masa kini, dan bukan tradisional. Karya tersebut dilindungi karena mempunyai nilai seni, baik dalam kaitannya dengan gambar, corak, maupun komposisi warna. Yang dimaksud dengan "karya seni motif lain" adalah motif yang merupakan kekayaan bangsa Indonesia yang terdapat di berbagai daerah, seperti seni songket, motif tenun ikat, motif tapis, motif ulos, dan seni motif lain yang bersifat kontemporer, inovatif, dan terus dikembangkan. Dengan demikian, maka seni motif lain termasuk didalamnya motif lubeng tenun ikat troso telah mendapat perlindungan hukum di dalam hukum positif di Indonesia. Ciptaan yang ada dalam ketentuan pasal tersebut dilindungi dalam lingkup wilayah dalam negeri maupun luar negeri. 
Untuk itu sangat dibutuhkan peranan pemerintah dalam melaksanakan perannya sebagai penegak hukum dan sadar akan pentingnya perlindungan hukum bagi karya cipta terutama seni motif lubeng tenun Troso. Perlindungan hukum terhadap motif lubeng, juga akan berguna untuk merangsang aktifitas kreatif, dan inovatif para perajin/pengusaha untuk terus-menerus berkarya dalam menciptakan desain motif-motif tenun yang baru. Perlindungan terhadap tenun troso secara keseluruhan ternyata belum diatur oleh pemerintah. Hal tersebut dikemukakan oleh bapak Abdul Basir bahwa perlindungan hukum terhadap tenun troso secara keseluruhan belum diatur. Menurut penulis, hal tersebut sangat disayangkan karena mengingat bahwa tenun troso adalah kekayaan intelektual yang merupakan warisan seni dan budaya oleh nenek moyang yang harus dilestarikan dan dijaga oleh generasi penerus bangsa.

Terkait perlindungan hukum tersebut, Pentingnya perlindungan hukum terhadap seni motif lubeng tenun Troso, yang merupakan salah satu kekayaan intelektual yang diciptakan oleh pengrajin tenun troso yang didalam proses penciptaan tersebut terdapat hak moral dan hak ekonomi yang harus dilindungi. Berkaitan dengan konsep perlindungan hukum tersebut. Robert M. Sherwood, mengemukakan teori tentang perlindungan hukum terhadap kekayaan intelektual, yakni:

- Reward Theory. Teori ini menjelaskan pengakuan terhadap karya intelektual yang telah dihasilkan oleh seseorang sehingga kepada penemu/pencipta atau pendesain harus diberikan penghargaan sebagai imbalan atas upaya-upaya kreatifnya dalam menemukan / menciptakan karya-karya intelektual tersebut.

- Recovery Theory. Teori ini menyatakan bahwa penemu/pencipta/pendesain yang telah mengeluarkan waktu, biaya, serta tenaga dalam menghasilkan karya intelektualnya harus memperole kembali apa yang dikeluarkan tersebut.

- Risk Theory. Teori ini menyatakan bahwa hak atas kekayaan intelektual merupakan suatu hasil karya yang mengandung risiko. Hak atas kekayaan intelektual yang merupakan hasil dari suatu penelitian mengandung resiko yang dapat memungkinkan orang lain yang terlebih dahulu menemukan cara tersebut memperbaikinya sehingga dengan demikian adalah wajar untuk memberikan suatu perlindungan hukum terhadap upaya kegiatan yang mengandung resiko tersebut.

- Economic Growth Stimulus Theory. Teori ini mengakui bahwa perlindungan atas KI merupakan suatu alat dari pembangunan ekonomi dan yang dimaksud dengan 
pembangunan ekonomi adalah keseluruhan tujuan dibangunnya suatu sistem perlindungan atas KI yang efektif.

Berdasarkan teori yang dikemukakan oleh Robert M. Sherwood diatas, penulis menganalisis bahwa perlindungan hukum Kekayaan Intelektual, terdapat Reward Theory yang memiliki makna yang sangat mendalam yang berupa pengakuan terhadap karya intelektual yang telah dihasilkan oleh seseorang sehingga kepada pencipta motif harus diberikan penghargaan sebagai imbalan atas upaya-upaya kreatifnya dalam menemukan/atau menciptakan karya-karya intelektual tersebut. Teori ini sejalan dengan prinsip yang menyatakan bahwa pencipta yang telah mengeluarkan waktu, biaya, serta tenaga dalam menghasilkan karya intelektualnya harus memperoleh kembali apa yang telah dikeluarkan tersebut, yang dikenal dengan Recovery Theory. Teori lain yang sejalan dengan teori Reward adalah Incentive Theory yang mengaitkan pengembangan kreativitas dengan memberikan insentif bagi para penemu/pencipta motif tersebut. Berdasarkan teori ini Insentif diberikan sebagai upaya untuk merangsang kreativitas dalam upaya menciptakan karya-karya baru dibidang tekhnologi.

Ketiga teori ini pada intinya memiliki visi yang sama berupa pemberian penghargaan kepada para Pencipta motif atas karya intelektual yang telah dihasilkan. Dalam perkembangannya pemberian penghargaan tersebut harus dikaitkan dengan upaya untuk menciptakan iklim kondusif agar masyarakat tetap kreatif, sebab penghargaan yang tidak memadai akan membunuh kreativitas masyarakat itu sendiri.

Teori keempat yang dikemukakan oleh Robert M. Sherwood adalah Risk Theory. Teori ini mengakui bahwa KI merupakan suatu hasil karya yang mengandung risiko yang dapat memungkinkan orang lain yang terlebih dahulu menemukan cara tersebut atau memperbaikinya sehingga dengan demikian adalah wajar untuk memberikan suatu bentuk perlindungan hukum terhadap upaya atau kegiatan yang mengandung risiko tersebut. Sherwood berpendapat bahwa risiko yang mungkin timbul dari penggunaan secara ilegal yang menimbulkan kerugian secara ekonomis maupun moral bagi Pencipta tersebut dapat dihindari jika terdapat landasan hukum yang kuat, yang berfungsi untuk melindungi KI tersebut. Namun dalam kenyataannya, kesulitan mengatasi risiko ini dapat pula timbul dari kelemahan dalam penegakan hukum meskipun hukum yang ada telah cukup memberikan perlindungan. Oleh karena itu, teori Risk harus diartikan secara luas, tidak hanya sekedar penyediaan 
perangkat hukum semata-mata, tetapi didalamnya juga harus diakomodasikan pula kemampuan aparat penegak hukum dalam proses penegakan hukum dan langkah untuk membudayakan perlindungan Hak cipta di kalangan masyarakat, mengingat risiko pelanggaran Hak cipta akan tetap potensial terjadi jika budaya masyarakat tidak mendukung perlindungan itu. Dengan demikian, teori Risk tersebut harus disempurnakan dengan memasukkan unsur-unsur sosial budaya sebagai faktor pendukung perlindungan Hak cipta.

Teori terakhir yang dikemukakan oleh Robert M. Sherwood adalah Economic Growth Stimulus Theory. Teori ini mengakui bahwa perlindungan atas Kekayaan intelektual merupakan suatu alat dari pembangunan ekonomi, dan yang dimaksud dengan pembangunan ekonomi adalah keseluruhan tujuan dibangunnya suatu sistem perlindungan atas Hak Kekayaan intelektual yang efektif. Menurut Sherwood, teori ini sangat relevan untuk dijadikan dasar perlindungan Hak Kekayaan Intelektual saat ini terutama dalam menghadapi era perdagangan bebas dan konsekuensi diratifikasinya kesepakatan WTO oleh Indonesia

Menurut penulis pada dasarnya perlindungan hukum yang diberikan oleh Undangundang No. 28 Tahun 2014 tentang hak cipta cukup maksimal, cukup maksimal tidak berarti bahwa perlindungan hukumnya memadai masih ada banyak hal yang perlu mendapat perhatian oleh UUHC. Seperti Hak Cipta atas motif lubeng tenun ikat troso, selain itu sikap pencipta untuk mau mendaftarkan hak ciptanya sesuai dengan amanat undang-undang Hak Cipta haruslah terus ditanamkan, karena ini adalah sesuatu yang amat penting tanpa kesadaran pencipta maka penegakan hukumnya akan mengalami kepincangan. Oleh karena itu, di sinilah peran dari pemerintah daerah beserta jajarannya untuk terus meningkatkan serta membangkitkan kesadaran dari pencipta dalam hal ini pengrajin tenun troso jangan hanya menjadi penonton dan terkesan pasif tetapi harus bersifat aktif memperjuangkan perlindungan terhadap hasil kebudayaan daerah. Mengenai pendaftaran hak cipta tersebut, sebenarnya pemerintah sudah menfasilitasi pendaftaran. Pendaftaran hak cipta tersebut bisa dilakukan secara online maupun tidak online, dan pendaftaran tersebut bisa dilakukan sendiri oleh pencipta maupun lewat konsultan kekayaan intelektual yang terdaftar dalam Ditjen KI. Pendaftaran secara online bertujuan untukmempermudah pemilik hak cipta untuk mendaftarkan karya ciptanya.

Hambatan dalam memberikan perlindungan hukum terhadap hak cipta seni motif lubeng tenun ikat troso ditinjau dari undang-undang nomor 28 tahun 2014 tentang hak cipta 
Banyak faktor yang menyebabkan pencipta maupun pengrajin tenun troso enggan untuk memanfaatkan Undang-undang No. 28 tahun 2014 tentang hak cipta. Berdasarkan fakta dilapangan yang menjadi faktor Diantaranya adalah faktor internal dan faktor eksternal.

Faktor internal yang pertama adalah kondisi masyarakat troso dan rendahnya tingkat kesadaran hukum pengrajin dan pengusaha terhadap hak cipta, hal tersebut dijelaskan pak asrofi bahwa hambatan yang paling mendasar adalah tingkat kesadaran masyarakat itu sendiri. Kemudian menurut bapak Abdul Basir. Hambatan yang mendasari perlindungan hukum yaitu terletak pada kondisi masyarakat troso itu sendiri. Hambatannya karena masyarakat desa troso ketika diajak bersatu itu agak susah, kemudian ketika ada salah satu pengrajin dan pengusaha mendapat peluang agak besar, nanti bisa saja disrobot oleh temannya sendiri.

Faktor hambatan yang kedua adalah mengenai pendaftaran hak cipta, mereka belum menganggap penting perlindungan hukum terhadap pendaftaran hak cipta, di samping karena biaya pendaftaran hak cipta yang relatif mahal dan prosedur pendaftaran yang berbelit-belit juga dikarenakan banyaknya syarat permohonan pendaftaran ciptaan yang harus dipenuhi. Fakta tersebut diperoleh dari hasil penelitian dengan nidho muniam, beliau menjelaskan bahwa kalau meng-hak patenkan hak cipta motif lubeng itu sedikit repot.

Kendala lain terkait dengan perlindungan hak cipta motif lubeng tenun ikat troso adalah karena faktor Budaya para pengrajin batik bahwa suatu penjiplakan atau peniruan motif batik merupakan suatu hal yang sudah biasa karena mereka beranggapan bahwa para pengusaha kecil merasa bahagia dan bangga kalau hasil karya cipta motif batik mereka bisa dinikmati oleh pihak lain sehingga mudah tersebar luas di masyarakat, secara tidak langsung dapat mengangkat produksinya. Fakta tersebut berdasarkan hasil penelitian dengan zuhrul anam, bahwa mengenai penjiplakan dan peniruan motif di troso itu sudah menjadi hal yang umum.

Faktor eksternal mengenai hambatan dalam perlindungan hak cipta motif lubeng adalah ketentuan hukum yang ada didalam Undang-undang No. 28 tahun 2014 tentang hak cipta kurang kuat. Hal tersebut berdasarkan wawancara dengan kuntariyono, beliau menjelaskan bahwa hukum diIndonesia kurang bagus, faktanya beliau sudah izin tentang hak cipta, tetapi bila dijiplak orang dengan dirubah sedikit motifnya, aspek hukumnya sudah tidak kuat. Tetapi jerih payah yang tidak sesuai dengan angan-angan para pengrajin dan pengusaha, karena orang menciptakan suatu karya cipta itu tidak semudah membalik tangan, sedangkan penghargaannya hanya demikian. Beliau menceritakan bahwa beliau sudah menempuh jalur 
hukum di pengadilan mengenai pelanggaran motif, tetapi upaya hukum tersebut gagal ditengah jalan, karena motif tenun apabila dirubah sedikit saja, hukumnya tidak kuat.

Berdasarkan data yang telah di paparkan diatas maka penulis menganalisis bahwa kendala dalam pentingnya perlindungan pendaftaran terhadap hak cipta motif lubeng tenun ikat troso yaitu dari sisi masyarakat itu sendiri khususnya para pengrajin dan pengusaha tenun troso itu sendiri kurang adanya minat untuk mendaftarkan motif tenun yang mereka miliki karena mengganggap prosedur yang berbelit belit dan biaya yang mahal. Oleh karena itu perlu adanya suatu upaya sosialisasi untuk meningkatkan kesadaran para pengusaha tenun troso, upaya sosialisasi telah ditempuh oleh Dinas Perindustrian, serta dari sub Bagian Hak Kekayaan Intelektual Kantor Wilayah Hukum dan Hak Asasi Manusia Jawa Tengah.

Upaya pemerintah untuk mengatasi hambatan dalam memberikan perlindungan hukum terhadap hak cipta seni motif lubeng tenun ikat troso ditinjau dari undang-undang nomor 28 tahun 2014 tentang hak cipta

Hasil penelitian mengenai Upaya Pemerintah Untuk Mengatasi Hambatan Dalam Memberikan Perlindungan Hukum Terhadap Hak Cipta Seni Motif Lubeng Tenun Ikat Troso adalah upaya preventif dalam bentuk sosialisasi dan pendampingan. Upaya preventif yang telah dilakukan oleh Kantor Wilayah Kementerian Hukum dan HAM Jawa Tengah dalam melihat persoalan hak cipta pada umumnya, hal tersebut dibuktikan dengan adanya pembaharuan Undang-Undang Hak Cipta, dimana dilakukan banyak penyempurnaan dan permbaharuan dari Undang-Undang Nomor. 19 Tahun 2002 tentang hak cipta digantikan dan dinyatakan tidak berlaku lagi dengan digantikan Undang-Undang Nomor 28 Tahun 2014 tentang Hak Cipta.

Sistem pendaftaran hak cipta di Indonesia menganut sistem pendaftaran deklaratif. Sistem ini menitik beratkan pada anggapan sebagai pencipta terhadap hak yang didaftarkan itu, sampai orang lain dapat membuktikan sebaliknya. Dengan kata lain, hak cipta itu didaftarkan undang-undang hanya mengakui seolah-olah yang bersangkutan sebagai pemiliknya, secara de jure harus dibuktikan lagi, jika ada orang lain yang menyangkal hak tersebut.

Adanya Undang-Undang Nomor 28 Tahun 2014 tentang Hak cipta dan berdampak memberi kemudahan bagi sistem pendaftaran hak cipta dari pada Undang-Undang hak cipta 
yang sebelumnya, dikarenakan adanya sistem baru yaitu pendaftaran secara online untuk mempermudah pemilik hak cipta untuk mendaftarkan ciptaannya.

Upaya preventif lain yang telah dilakukan oleh pemerintah dalam hal ini adalah oleh Dinas Perindustrian dan perdagangan Kabupaten Jepara dan Kantor Wilayah Kementerian Hukum dan HAM Jawa Tengah telah melakukan upaya sosialisasi untuk meningkatkan kesadaran mengenai pentingnya pendaftaran hak cipta kepada para pengrajin dan pengusaha tenun troso dan juga melakukan upaya pembinaan dan pendampingan kepada para pengrajin dan pengusaha tenun troso di Jepara.

Fakta tersebut disampaikan oleh Ali ma'mum bahwa pemerintah sudah melakukan upaya sosialisasi untuk mengatasi hambatan yaitu dalam bentuk pendampingan, terutama dalam perlindungan hukum dan upaya pendampingan dalam membantu pemasaran.

Senada dengan Ali ma'mum, dalam upaya untuk mengatasi hambatan, setyawati meminta kepada stakeholder yang membidangi untuk melakukan sosialisasi dan pendampingan terhadap masyarakat, terutama kepada pengrajin dan pengusaha tenun troso, supaya mereka mengetahui dan memahami hak mereka dengan cara melakukan pembimbingan. Setelah sosialisasi atau mungkin memberi fasilitasi dengan memberi bantuan untuk pendaftaran kepada para pengrajin dan pengusaha tenun troso yang tidak mampu, sedangkan bagi pengrajin dan pengusaha yang mampu, harus melakukan pendaftaran, kemudian pemerintah juga harus melakukan infentarisasi terhadap motif-motif yang sudah diciptakan oleh para pengrajin dan pengusaha tenun troso di Jepara, supaya pengrajin dan pengusaha tersebut tetap terlindungi. Maka dari itu negara harus hadir dalam setiap kondisi apapun, jadi itu dua hal yang perlu dilakukan untuk mengantisipasi supaya pengrajin dan pengusaha mendapat perlindungan hukum dan meminimalisir terhadap kejahatan pembajakan. Kemudian pemerintah setempat harus membuat regulasi dalam bentuk perda atau peraturan perundang-undangan kalau tingkat pusat, ini kan sudah ada undang-undangnya nomor 28 tahun 2014, pemerintah setempat dalam hal ini adalah pemerintah Kabupaten Jepara harus membuat perda yang mengatur tentang perlindungan tenun troso di Kabupaten Jepara, dan itu harus selalu dianggarkan, khususnya untuk memberi fasilitas pendaftaran. Kemudian khususnya kepada Disperindag kabupaten jepara dan paguyuban tenun troso harus mengalokasikan untuk bisa membantu para pengrajin dan pengusaha tenun troso, supaya memperoleh haknya dibidang kekayaan intelektual khususnya karya cipta. 
Apabila kesadaran hukum dari para perajin dan pengusaha tenun troso ini sudah terbentuk maka pelanggaran dalam bentuk apapun dapat diminimalisir dengan segera sehingga ketenangan berkerja dan berusaha akan tercipta. Selain itu etika usaha antara para pengrajin tenun troso juga perlu ditingkatkan sehingga persaingan sehat pun dapat tercipta diantara mereka.

Kantor Wilayah Kementerian Hukum dan HAM Jawa Tengah memfasilitasi jika ada pihak yang keberatan/dirugikan terkait hak cipta dapat melaporkan kepada Kantor Wilayah Kementerian Hukum dan HAM Jawa Tengah yang selanjutnya akan diproses secara lebih lanjut sesuai dengan prosedur yang ada dalam Undang-Undang Nomor 28 Tahun 2014 tentang Hak cipta.

\section{KESIMPULAN}

Alasan pengrajin dan pengusaha tenun troso tidak memanfaatkan instrumen pendaftaran Hak Cipta Motif lubeng tenun ikat troso antara lain masih rendahnya tingkat kesadaran hukum pengrajin dan pengusaha tenun troso dan prosedur pendaftaran hak cipta yang berbelit-belit. Faktor-faktor yang menjadi hambatan dalam upaya perlindungan hukum terhadap hak cipta motif lubeng tenun ikat troso dalam Undang-Undang Nomor 28 Tahun 2014 tentang Hak Cipta, meliputi: a). Masih banyak pengrajin dan pengusaha tenun troso yang belum memahami adanya Undang-Undang Hak Cipta, khususnya para pengrajin dan pengusaha tenun troso di tingkat menegah ke bawah. Sehingga perlindungan hukum terhadap pengrajin dan pengusaha belum dapat dilaksanakan secara maksimal. b). prosedur yang berbelit-belit dalam proses pendaftaran hak cipta. c). Budaya para pengrajin dan pengusaha tenun troso yang beranggapan bahwa suatu penjiplakan atau peniruan motif tenun troso merupakan suatu hal yang sudah biasa. Upaya yang dilaksanakan pemerintah yakni dalam hal sosialisasi mengenai pentingnya perlindungan hak cipta terhadap tenun troso sudah terselesaikan dengan baik.

\section{REFERENSI}

Agus, S. (2010). Hak kekayaan intelektual dan pengetahuan tradisional. Bandung: PT. Alumni.

Akmi, A. (2016). Perlindungan hukum terhadap hak cipta seni motif tenun songket pandai sikek ditinjau dari undang-undang nomor 28 tahun 2014 tentang hak cipta. Jurnal hukum. Vol. 3 no 2. 
Besen, S. M., Manning Jr, W. G., \& Mitchell, B. M. (1978). Copyright Liability for Cable Television: Compulsory Licensing and the Coase Theorem. The Journal of Law and Economics, 21(1), 67-95.

Ekstrand, V. S., \& Silver, D. (2014). Remixing, reposting, and reblogging: Digital media, theories of the image, and copyright law. Visual Communication Quarterly, 21(2), 96-105.

Fanani, R. (2015). Perlindungan hukum hak cipta terhadap pencipta motif seni batik kontemporer di Yogyakarta. Yogyakarta, program studi ilmu Hukum, Fakultas Syari'ah dan Hukum Universitas Islam Negeri Sunan Kalijaga Yogyakarta.

Hanifah, M. (2015). Perlindungan hukum terhadap hak cipta hasil tenun songket melayu, jurnal hukum, fakultas hukum universitas riau, Vol. 5 no. 2.

Hasan, U \& Suhermi. (2013). Perlindungan hukum terhadap hak cipta menurut undangundang nomor 19 tahun 2002. Jurnal ilmu hukum. Fakultas hukum universitas jambi, Vol. 4 no 1.

Lona, H, \& Emily, S. (2012). Moral rights in the modern world: is it time for a change?. Journal of intellectual property law. Vol. 7 no 8.

Mayana, R. F. (2004). Perlindungan desain industry di Indonesia. Jakarta: Grasindo.

Muhammad, A. (2004). Hukum dan penelitian hukum. Bandung: Citra Aditya bhakti.

Putra, A.A. (2013). Perlindungan hukum terhadap sarung sutera wajo. Makasar, Fakultas Hukum Universitas Hasanuddin.

Rachmadi, U. (2003). Hukum hakatas kekayaan intelektual. Bandung: PT Alumni.

Saidin. (1995). Aspek hukum kekayaan intelektual. Jakarta: Raja Grafindo Persada.

Senewe, E.V.T. (2015). Efektivitas pengaturan hak cipta dalam melindungi karya seni traditional daerah. Jurnal hukum. Fakultas Hukum Universitas Samratulangi. Vol. 2 no 2.

Sinungan, A. (2007). Pengertian hak cipta. Jakarta: Departemen Hukum dan Ham RI.

Suhersono, H. (2005). Desain bordir motif Fauna. Jakarta: PT Gramedia Pustaka Utama.

Sutedi, A. (2009). Hak atas kekayaan intelektua. Jakarta: Sinar Grafika.

Undang-Undang Nomor 28 Tahun 2014 Tentang Hak Cipta.

Zulva, M. (2016). Aspek hak ekonomi dan hak moral dalam hak cipta. Jurnal Akta Yudisia. Vol. 1 no 1. 